\title{
Detection of human papillomavirus type 2 related sequence in oral papilloma
}

\author{
Taihei Yamaguchi ${ }^{\mathrm{a}, \mathrm{b}, \mathrm{e}, *}$, Masanobu Shindoh ${ }^{\mathrm{c}, \mathrm{e}}$, Akira Amemiya $^{\mathrm{c}}$, Nobuo Inoue $^{\mathrm{d}}$, \\ Masaaki Kawamura ${ }^{\mathrm{d}}$, Hiroshi Sakaoka ${ }^{\mathrm{b}}$, Masakazu Inoue ${ }^{\mathrm{a}}$ and Kei Fujinaga ${ }^{\mathrm{e}}$ \\ ${ }^{a}$ Department of Preventive Dentistry, Kagoshima University Dental School, Kagoshima, Japan \\ Departments of ${ }^{\mathrm{b}}$ Oral Microbiology, ${ }^{\mathrm{c}}$ Oral Pathology and ${ }^{\mathrm{d}}$ Oral Surgery, Hokkaido University \\ Dental School, Sapporo, Japan \\ ${ }^{\mathrm{e}}$ Department of Molecular Biology, Sapporo Medical College, Sapporo, Japan
}

Received 2 June 1997

Revised 26 February 1998

Accepted 26 February 1998

\begin{abstract}
Oral papilloma is a benign tumourous lesion. Part of this lesion is associated with human papillomavirus (HPV) infection. We analysed the genetical and histopathological evidence for HPV type 2 infection in three oral papillomas. Southern blot hybridization showed HPV 2a sequence in one lesion. Cells of the positive specimen appeared to contain high copy numbers of the viral DNA in an episomal state. In situ staining demonstrated virus capsid antigen in koilocytotic cells and surrounding cells in the hyperplastic epithelial layer. Two other specimens contained no HPV sequences by labeled probe of full length linear HPVs 2a, 6b, 11, 16, 18, 31 and 33 DNA under low stringency hybridization conditions. These results showed the possibility that HPV 2 plays a role in oral papilloma.
\end{abstract}

Keywords: Human papillomavirus type 2, oral papilloma, in situ immunostaining, southern blot hybridization

\section{Introduction}

More than 70 human papillomavirus (HPV) types have been reported. HPV 2 can replicate in the epithelium of skin [13], oral and anal lesions [4,17]. In the oral cavity, the HPV 2 sequence has been identified in squamous cell carcinoma [6] and verrucous carcinoma [2] as well as verruca vulgaris $[14,16]$. In spite of the high detection rate, HPV 2 has not been described as fully as HPV 6, 11, 16 and 18 owing to the absence of a clear proof of malignancy.

In the oral cavity, papilloma is a frequent benign tumourous lesion. The predominant sites are the tongue and the palate, and there is no clear difference between male and female. Histopathologically, this lesion shows peduncular exophytic growth with a fibrous connective tissue core covered by epithelial papillary projections. The epithelium shows parakeratosis and hyperkeratosis. Atypia has been reported in a part of this lesion [1]. Frequent hyperkeratosis, koilocytosis, dyskeratosis, papillomatosis and acanthosis suggest possible HPV infection $[11,18,19]$. However, all such lesions were not of viral

\footnotetext{
*Corresponding author: Taihei Yamaguchi, Department of Preventive Dentistry, Kagoshima University Dental School, 8-35-1 Sakuragaoka, Kagoshima 890-8544, Japan. Tel.: +81 99275 6182; Fax: +81 992756019.
} 
origin. HPV particles and/or antigens were seen in part of oral papillomas [9,15]. HPV 1 antigen was detected in two out of 50 oral papilloma specimens [20]. Association with HPV 2 has not been reported to date.

In this study, we investigated 3 oral papillomas for HPV 2 infection by southern blot hybridization, and the localization of HPV capsid antigens within tumour tissue by in situ antigen staining.

\section{Materials and methods}

\subsection{Tissue specimens and histopathological study}

Tissue biopsies which were clinically diagnosed as tumourous lesions of the oral cavity from 34 patients attending the clinics of the Dental Hospital of Hokkaido University, Sapporo, Japan, for one year were selected for this study. All surgical tumour biopsis were collected prior to any kind of therapy.

For the histopathological study, one half from each biopsy specimen was fixed in $10 \%$ neutral buffered formalin, embedded in paraffin, cut and stained with hematoxylin-eosin. Three pathological specimens diagnosed as papilloma are shown in Table 1.

\subsection{DNA extraction and southern blot hybridization}

The other half from each specimen was washed with phosphate-buffered saline and cut with a surgical scalpel on glass as finely as possible. The diced pieces were suspended in a solution containing $1 \mathrm{mM}$ EDTA, $0.5 \%$ sodium dodecyl sulfate (SDS) and $10 \mathrm{mM}$ Tri-HCI (pH 8.0), and then digested overnight with $50 \mu \mathrm{g} / \mathrm{ml}$ proteinase $\mathrm{K}$ at $37^{\circ} \mathrm{C}$. DNA was purified by extraction with phenol equilibrated with chloroform: isoamyl alcohol $(24: 1)$ twice and dialized to $10 \mathrm{mM}$ Tris-HCI (pH 8.0)-1 mM EDTA (TE). The resulting DNA solution was treated with $20 \mu \mathrm{g} / \mathrm{ml}$ RNase A at $37^{\circ} \mathrm{C}$ for $30 \mathrm{~min}$ and digested with $50 \mu \mathrm{g} / \mathrm{ml}$ proteinase $\mathrm{K}$ in $0.5 \%$ SDS at $37^{\circ} \mathrm{C}$ for $2 \mathrm{~h}$, followed by extraction with the above phenol solution three times. The DNA solution was then dialized to TE (pH 8.0).

The southern blot hybridization was as described previously [23]. In brief, $10 \mu \mathrm{g}$ of DNA was digested with restriction enzyme(s), electrophoresed in $1 \%$ agarose gel, and transferred onto a nylon membrane filter NYTRAN N13N (Schleicher \& Schull, Dassel, Germany). Filters were hybridized with labeled HPV probe DNA and washed under low or high stringency conditions. The probes used were linear full length HPVs $2 \mathrm{a}, 6 \mathrm{~b}, 11,16,18,31$ or 33 DNA separated from the vector plasmid by the appropriate restriction enzyme digestion and agarose gel electrophoresis, and labeled with $\alpha$-phosphorus-32 $\left({ }^{32} \mathrm{P}\right)$-dCTP using Random Primer DNA Labeling Kit (Takara Shuzo Co., Otsu, Japan). Autoradiography was performed at $-80^{\circ} \mathrm{C}$.

Table 1

Clinicopathological characteristics of the biopsy specimens

\begin{tabular}{cccll}
\hline Case no. & Age & Sex $^{\mathrm{a}}$ & Clinical diagnosis & Pathological diagnosis \\
\hline 1 & 34 & $\mathrm{~F}$ & Tumour of tongue & Papilloma \\
2 & 23 & $\mathrm{~F}$ & Tumour of lip & Papilloma \\
3 & 29 & M & Tumour of upper gingiva & Papilloma \\
\hline
\end{tabular}

${ }^{\mathrm{a}} \mathrm{M}$, male; F, female. 


\subsection{In situ detection of HPV capsid antigen}

The staining procedure was as described previously [23]. Anti-bovine papillomavirus (BPV) capsid serum was purchased from Dako Co., Santa Barbara, CA, USA, and unimmunized rabbit serum was the negative control. The paraffin sections were incubated with one of the above primary antisera, followed by detection by the avidin-biotin-peroxidase. The chromogenic substrate reagent for detection was $0.02 \%$ hydrogen peroxide and $0.05 \% 3,3^{\prime}$-diaminobenzidine tetrahydrochloride.

\section{Results}

Southern blot hybridization analysis was carried out to detect HPV 2 sequence. One specimen was hybridized with labeled full length HPV 2a DNA probe under high stringency conditions. The size of the detected Bam HI digested fragment was approximately $6.0 \mathrm{kbp}$ (Fig. 1(A)), and the Pst I digested pattern was somewhat different from that of typical HPV 2a-e. The sizes of the observed dominant hybridized bands were 5.2, 4.1, 3.9, 2.3, 1.5 and $0.7 \mathrm{kbp}$. Some additional minor bands may be due to partial digestion (Fig. 1(B)). This specimen contained high copy numbers of HPV 2 genomes judging from the intensity of the developed bands of one copy marker. The other two specimens showed no positive-hybridized bands on all types of HPV probe containing HPV 2a under both low and high stringency conditions (data not shown).

The HPV genome positive specimen was investigated pathologically in detail (Fig. 2(A) and (B)). This case revealed irregular proliferation of the epithelium. The surface of the epithelium showed

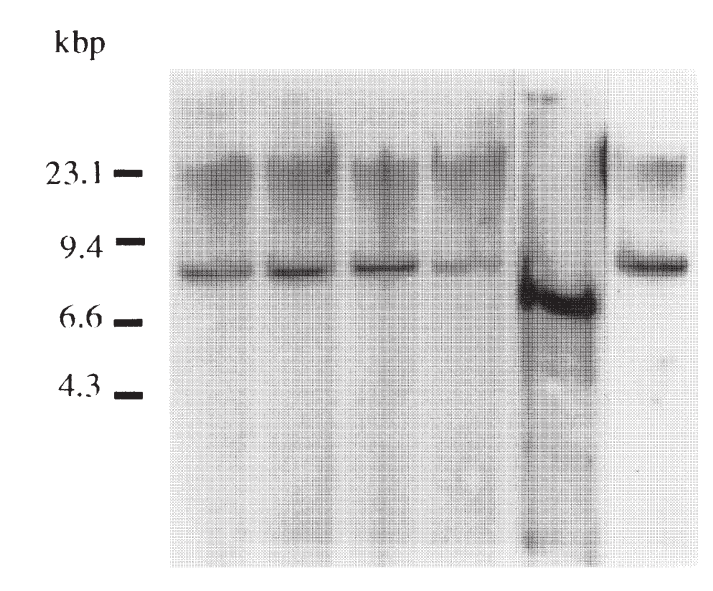

(A)

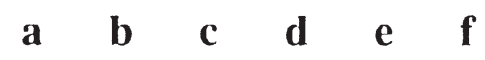

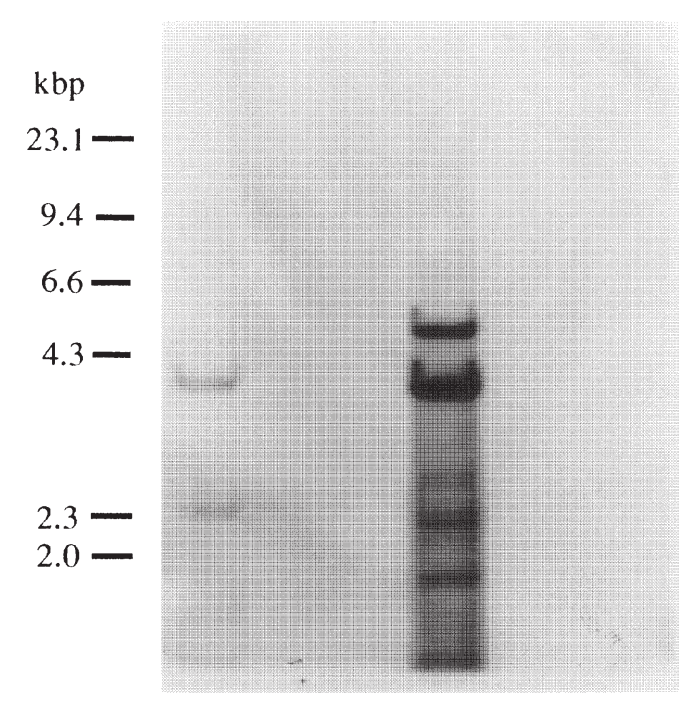

(B) $\begin{array}{lllllll}\text { a } & \mathbf{b} & \mathbf{c} & \mathbf{d} & \mathrm{e} & \mathbf{f}\end{array}$

Fig. 1. Southern blot hybridization of oral lesion DNA in case 2 with HPV DNA probe(s). (A) DNA was digested with Bam HI and hybridized with a mixed ${ }^{32}$ P-labeled probe containing HPVs 2a, 6b, 11, 16 and 18 DNA under low stringency conditions (lane e). Lanes $\mathrm{a}, \mathrm{b}, \mathrm{c}, \mathrm{d}$ and $\mathrm{f}$ show one copy positive marker of each of the above HPV types at full length linear state. (B) DNA in case 2 was digested with both Eco RI and Pst I, and hybridized with linear ${ }^{32} \mathrm{P}-$ labeled HPV $2 \mathrm{a}$ probe under high stringency conditions (lane d). Lanes a, b, c, e and f were Pst I digested DNA of full length linear HPVs 2a, 6b, 11, 16 and 18 DNA, respectively. Bars at the left show the pattern of lambda DNA digested with Hind III as size marker. 

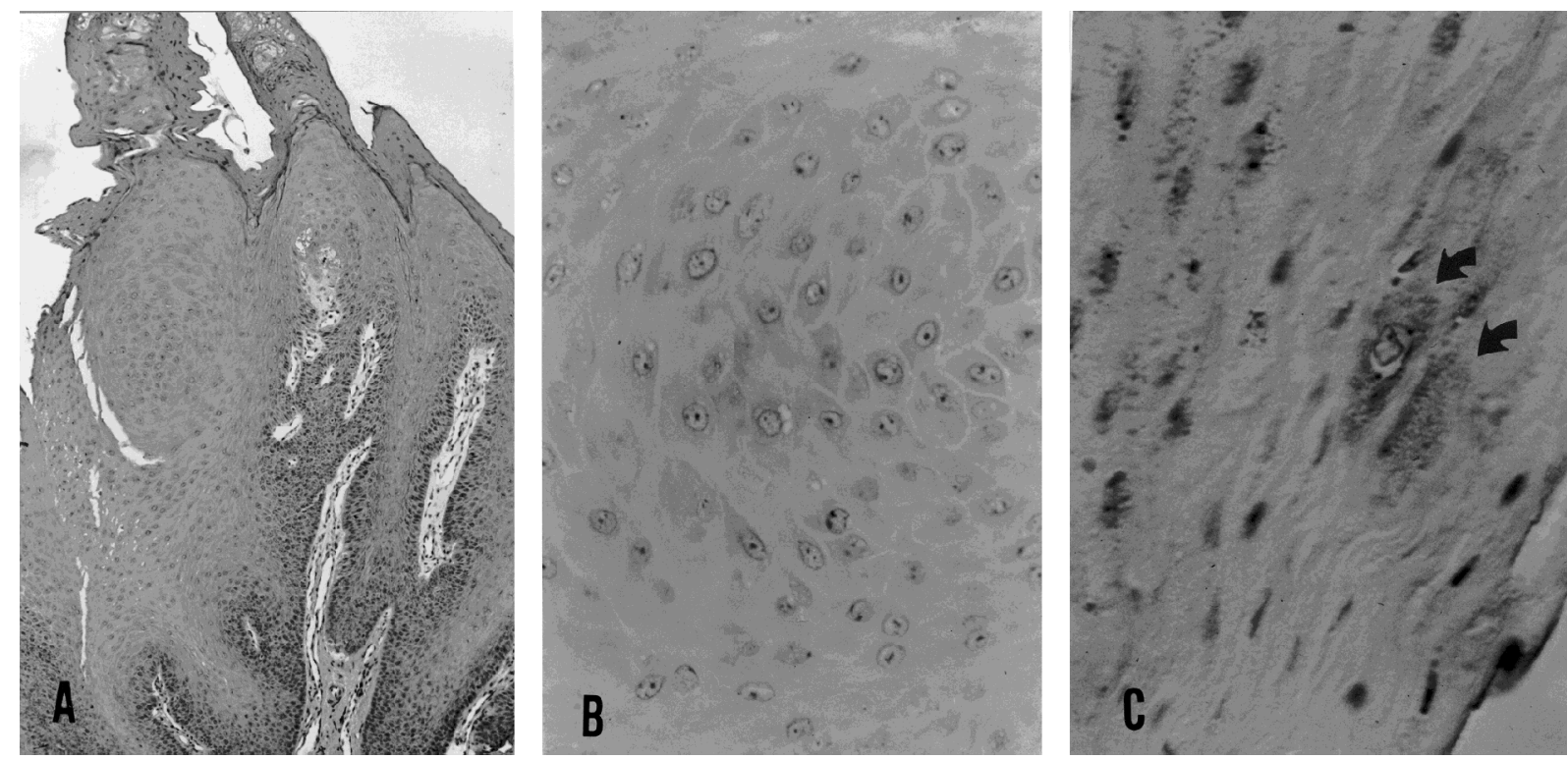

Fig. 2. Histopathological views of case 2 diagnosed as papilloma. Irregular proliferation of the epithelium was noted (A), but epithelial cells showed no atypia (B). (Hematoxylin-eosin stain $(\mathrm{HE})$; original magnification $\times 20$ (A) and $\times 100$ (B).) (C) In situ staining of HPV antigen. The arrows show papillomavirus capsid antigens. Stained cells are koilocytes and surrounding cells. (Immunoperoxidase satin with BPV capsid antiserum; original magnification $\times 200$.)

moderate to severe parakeratotic hyperkeratosis, and acanthomatous proliferations were also noted. A few mitotic figures were seen in the basal layer of the epithelium, but no atypical cells were observed. Koilocytic cells were present in the stratum granulosum of the epithelial layer.

Staining with BPV antiserum showed papillomavirus capsid antigen in this HPV 2 DNA positive specimen (Fig. 2(C)). Positive signals were detected in the cytoplasm of koilocytotic cells and surrounding cells throughout the hyperplastic epithelial layer of the lesional region. None of the positive signals were detected when unimmunized rabbit serum was used instead of the BPV antiserum.

\section{Discussion}

One of the three oral papillomas contained HPV 2 DNA sequence with high copy number per cell and the other two cases contained no HPV sequences on southern blot hybridization. The positive specimen had the typical pathological features of HPV infection. Some koilocytes and surrounding cells were stained with BPV antiserum.

Subtyping for HPV 2 is mainly based on the Pst I digestion pattern. At present, HPV 2 is divided into a-e subtypes $[12,22]$. The Pst I digested profile of the present virus was somewhat different from published patterns of HPV 2a-e. However, the 4.1, 2.3, $0.7 \mathrm{kbp}$ fragments of Pst I digestion and the $6.0 \mathrm{kbp}$ fragment of Bam HI digestion were identified with Pst I A, B, C and Bam HI A fragments of HPV 2a, respectively. These results strongly indicate that the present virus is HPV type 2a. Other Pst I bands were probably partially digested fragments.

Moreover, the absence of off-sized bands suggests that the viral genome is in the episomal state in vivo. Since linear viral genome exists within cell chromosomal DNA in the integrated state, the restriction fragments containing integration sites show off-sized high molecular weight bands. Two 
dimensional gel electrophoresis is very useful to see whether the HPV genome is integrated in host cell DNA or maintained in an episomal state [21]. Unfortunately, further examination could not be carried out due to a lack of specimens. The integrated state of HPV 2 has not been reported.

Since not all cells in the positive tissue material contained HPV sequence, the possible viral copy number per cell derived from the depth of hybridized bands is not accurate. Large copy numbers of HPV 2 per cell were detected in a squamous cell carcinoma of tongue base and in verrucous carcinomas in some oral regions $[6,14]$, suggesting that amplification of the viral genome in the infected cell is required for tumourigenesis. Episomal amplification in tumourigenic state has been demonstrated for HPV 16 [3] and BPV 1 [10].

In this case, positive staining for papillomavirus antigens with in situ immunostaining was confined to intracytoplasm rather than nuclei of koilocytes and surrounding cells. Previous reports specified intranuclear staining as positive, but positive cytoplasmic staining was detected in some cases as in the present study $[7,15]$. The cytoplasmic staining was suggested to be the result of release of viral particles and virus associated proteins, and may be associated with specific HPV type(s).

Whether oral papilloma derives from viral infection is still unclear. Previous studies report HPV prevalence in oral papilloma varying from $4 \%$ [20] to $83 \%$ [11] using various detection methods. On the other hand, it is thought that most of the oral papillomas are the result of reactive proliferation by constant traumatic defects and that the remaining cases are true tumours. It is extremely difficult to discriminate between these two types. The various detection rate may due to this reason and/or the methods used.

In recent decades, new detection methods have been developed. The PCR method gives especially good sensitivity. But this method gives false-positive results due to carryover [8]. Since in situ hybridization and in situ immunostaining are carried out in paraffin-embedded tissues, these methods are useful for retrospective screening and treatment of larger numbers of specimens and show the localization of HPV histologically. The HPV detective sensitivity varied widely according to the investigator and the used method [5], suggesting that the interpretation of HPV prevalence was very difficult. In spite of some disadvantages, southern blotting is valuable even now for additional information, such as integration and subtyping. By using low stringent hybridization with more types of HPV probe, which allows the detection of more distantly related HPV sequences, it may be possible to clarify the role of HPV in oral papilloma. Investigation of the clinical and histopathological features of oral papilloma for each detectable type of HPV is also necessary.

\section{Acknowledgements}

We thank Dr. H. zur Hausen for providing cloned HPV 2a, 6b, 11, 16 and 18 (through the Japanese Cancer Research Resources Bank), Dr. A.T. Lorincz for HPV 31 and Dr. G. Orth for HPV 33.

\section{References}

[1] L.M. Abbey, D.G. Page and D.R. Sawyer, The clinical and histopathologic features of a series of 464 oral squamous cell papillomas, Oral Surg. Oral Med. Oral Pathol. 49 (1980), 419-428.

[2] K. Adler-Storthz, J.R. Newland, B.A. Tessin, W.A. Veudall and E.J. Shillitoe, Human papillomavirus type 2 DNA in oral verrucous carcinoma, J. Oral Pathol. 15 (1986), 472-475.

[3] P.J. Bavin, J.A. Giles, A. Deery, J. Crow, P.D. Griffiths, V.C. Emery and P.G. Walker, Use of semi-quantitative PCR for human papillomavirus DNA type 16 to identify women with high grade cervical disease in a population presenting with a mildly dyskaryotic smear report, Br. J. Cancer 67 (1993), 602-605. 
[4] F. Chang, S. Syrjänen, J. Kellekoski and K. Syrjänen, Human papillomavirus (HPV) infections and their associations with oral disease, J. Oral Pathol. Med. 20 (1991), 305-317.

[5] A.M. De Roda Husman, J.M. Walboomers, E. Hopman, O.P. Bleker, T.M. Helmerhorst, L. Rozendaal, F.J. Voorhorst and C.J. Meijer, HPV prevalence in cytomorphologically normal cervical scrapes of pregnant women as determined by PCR: The age-related pattern, J. Med. Virol. 46 (1995), 97-102.

[6] E.M. De Villiers, H. Weidauer, H. Otto and H. zur Hausen, Papillomavirus DNA in human tongue carcinomas, Int. J. Cancer 36 (1985), 575-578.

[7] L.R. Eversole, P.J. Laipis, P. Merrell and E. Choi, Demonstration of human papillomavirus DNA in oral condyloma acuminatum, J. Oral Pathol. 16 (1987), 266-272.

[8] P. Fouret, F. Martin, A. Flahault and J.L. Saint-Guily, Human papillomavirus infection in the malignant and premalignant head and neck epithelium, Diagn. Mol. Pathol. 4 (1995), 122-127.

[9] L. Frithiof and J. Wersäll, Virus-like particles in papillomas of the human oral cavity, Arch. Gesamte Virusforsch. 21 (1967), 31-44.

[10] M.F. Law, D.R. Lowy, I. Dvoretzky and P.M. Howley, Mouse cells transformed by bovine papillomavirus contain only extrachromosomal viral DNA sequences, Proc. Natl. Acad. Sci. USA 78 (1981), 2727-2731.

[11] T. Löning, P. Reichart, M.J. Staquet, J. Becker and J. Trivolet, Occurrence of papillomavirus structural antigens in oral papillomas and leukoplakias, J. Oral Pathol. 13 (1984), 155-165.

[12] S. Obalek, S. Jablonska, M. Favre, L. Walczak and G. Orth, Condylomata acuminata in children: Frequent association with human papillomaviruses responsible for cutaneous warts, J. Am. Acad. Dermatol. 23 (1990), 205-213.

[13] G. Orth, S. Jablonska, F. Breitburd, M. Favre and O. Croissant, The human papillomaviruses, Bull. Cancer 65 (1978), $151-164$.

[14] A. Padayachee, Strong signals with HPV type 2 and 57 in oral verrucae by in situ hybridization, J. Oral Pathol. Med. 23 (1994), 413-417.

[15] A. Padayachee and C.W. van Wyk, Human papillomavirus (HPV) in oral squamous cell papillomas, J. Oral Pathol. 16 (1987), 353-355.

[16] S. Syrjänen, Viral infections in oral mucosa, Scand. J. Dent. Res. 100 (1992), 17-31.

[17] S.M. Syrjänen, K.J. Syrjänen, R.M. Happonen and M.A. Lamberg, In situ DNA hybridization analysis of human papillomavirus (HPV) sequences in benign oral mucosal lesions, Arch. Dermatol. Res. 279 (1987), 543-549.

[18] S. Syrjänen, K. Syrjänen, H. Ikenberg, L. Gissmann and M. Lamberg, A human papillomavirus closely related to HPV 13 found in a focal epithelial hyperplasia lesion (Heck disease), Arch. Dermatol. Res. 276 (1984), 199-200.

[19] K. Syrjänen, S. Syrjänen, M. Lamberg and J. Pyrhönen, Morphological and immunohistochemical evidence suggesting human papillomavirus (HPV) involvement in oral squamous cell carcinogenesis, Int. J. Oral Surg. 12 (1983), 418-424.

[20] T.B. Welch, B.F. Barker and C. Williams, Peroxidase-antiperoxidase evaluation of human oral squamous cell papillomas, Oral Surg. Oral Med. Oral Pathol. 61 (1986), 603-606.

[21] F.O. Wettstein and J.G. Stevens, Variable sized free episomes of shope papillomavirus DNA are present in all nonvirus-producing neoplasms and integrated episomes are detected in some, Proc. Natl. Acad. Sci. USA 79 (1982), 790-794.

[22] C.A. Wilson, S.C. Holmes, M.S. Campo, S.I. White, D. Tillman, R.M. Mackie and J. Thomson, Novel variants of human papillomavirus type 2 in warts from immuno compromised individuals. Br. J. Dermatol. 121 (1989), 571-576.

[23] T. Yamaguchi, M. Shindoh, A. Amemiya, K. Notani, H. Fukuda, H. Sakaoka, M. Inoue and K. Fujinaga, Identification of human papilloma virus DNA sequence in the hyperplastic epithelium of an oral denture fibroma, Dis. Mark. 13 (1996), 1-6. 


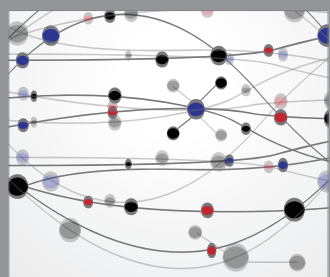

The Scientific World Journal
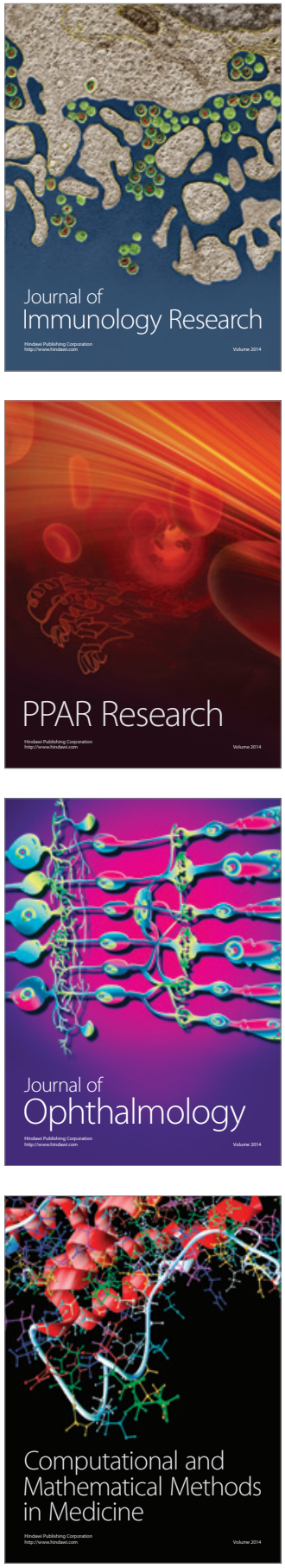

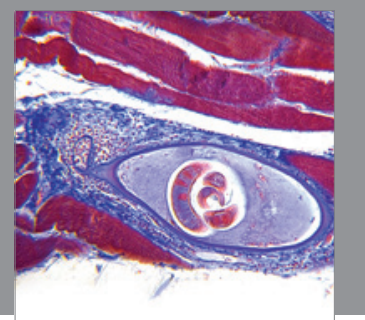

Gastroenterology

Research and Practice
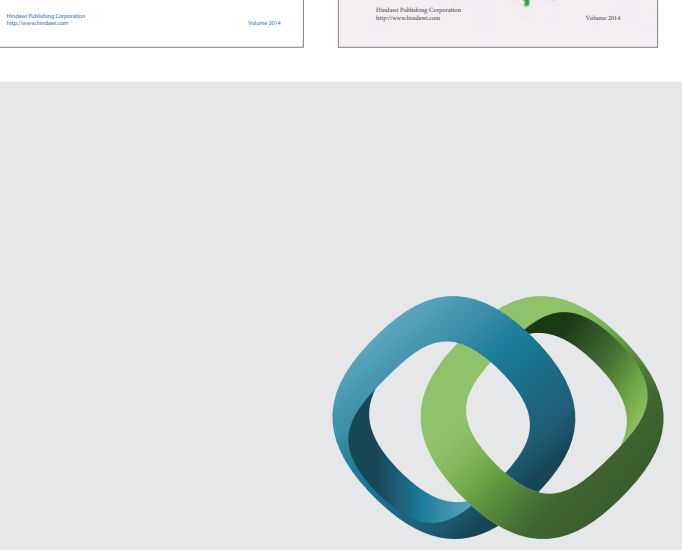

\section{Hindawi}

Submit your manuscripts at

http://www.hindawi.com
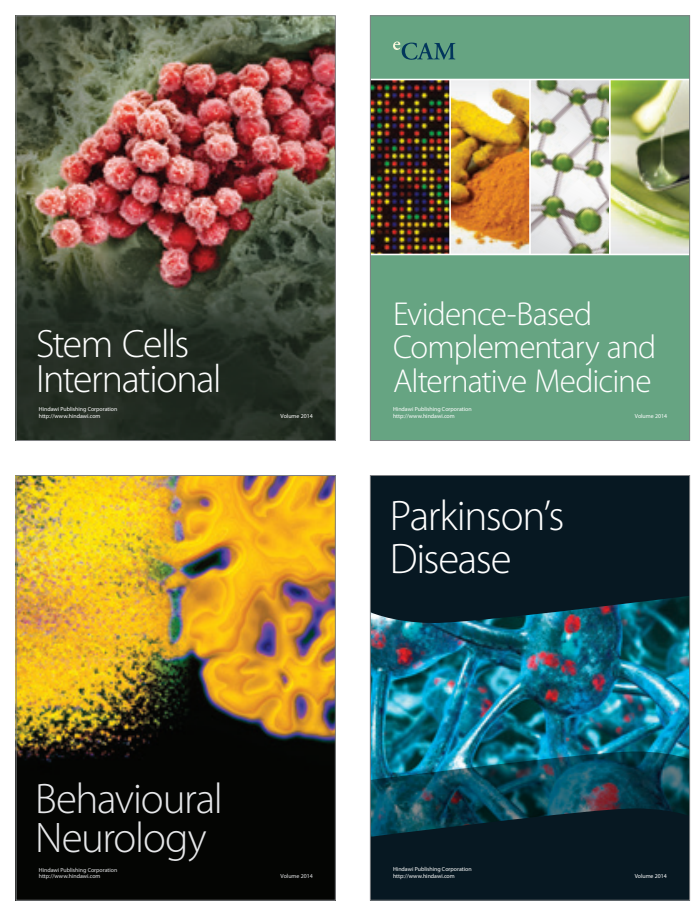

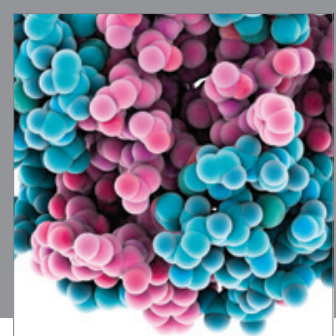

Journal of
Diabetes Research

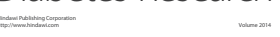

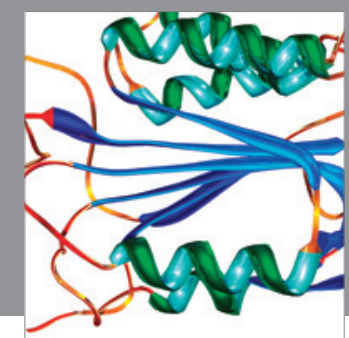

Disease Markers
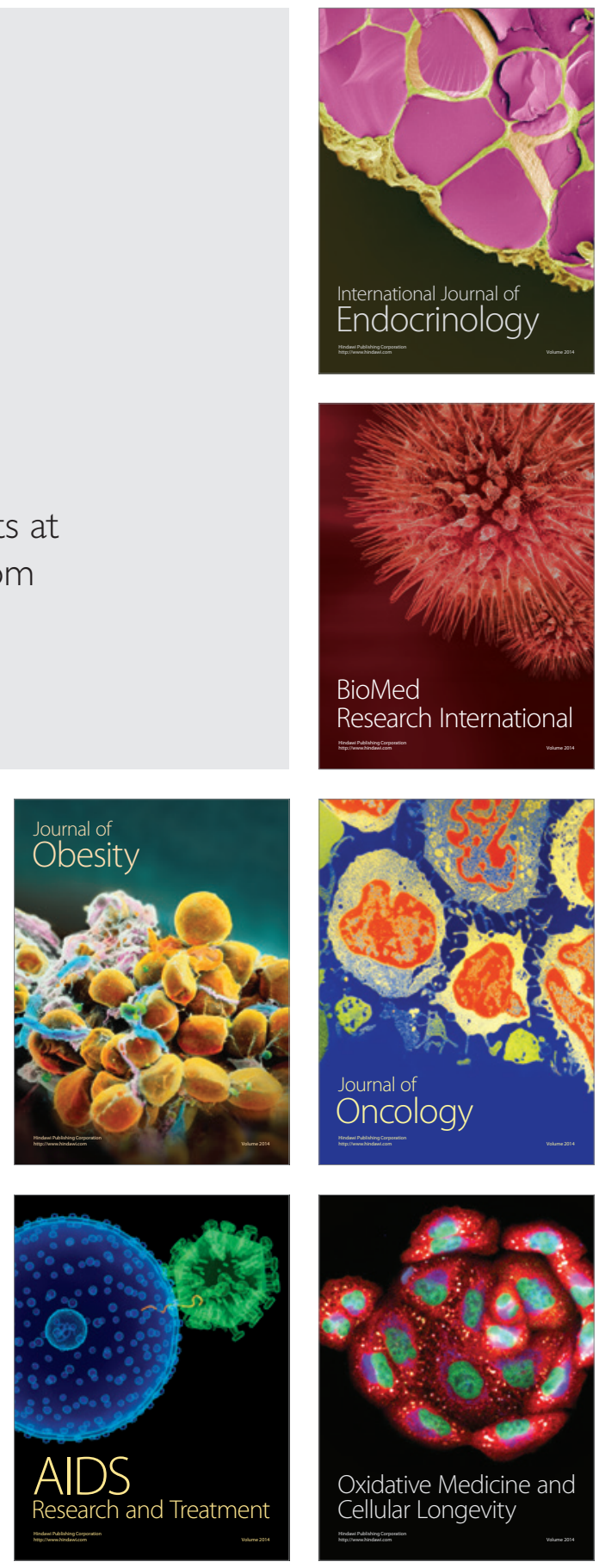